\title{
42. REVISED TERTIARY SEISMIC STRATIGRAPHY OF THE SOUTHERN ROCKALL TROUGH ${ }^{1}$
}

\author{
D. G. Masson and R. B. Kidd, Institute of Oceanographic Sciences, Wormley²
}

\begin{abstract}
DSDP Site 610 is on the crest of the Feni Ridge sediment drift in the southern Rockall Trough. Within the sediment section in the Rockall Trough, we recognize eight seismic reflectors, which can be correlated over all or most of the area. These are coded yellow, purple, green, brown, blue, pink, orange, and gray, in order of increasing age. The blue reflector is believed to mark the approximate base of the Tertiary section. A late Eocene to early Oligocene age is inferred for the brown reflector, which marks the initiation of sediment drift accumulation. Drilling at Site 610 penetrated to just below the green reflector, previously assigned a late Eocene to early Oligocene age but now dated as late early Miocene. This reflector results from a rapid downward increase in seismic velocity between 625 and $675 \mathrm{~m}$ sub-bottom, apparently caused by a downward increase in hardness due to compaction and silica diagenesis. The yellow reflector correlates with a period of reduced sedimentation rates or erosion during the latest late Miocene. This event, apparently restricted to the Rockall Plateau and Trough area, could mark an oceanographic "disturbance" related to the isolation of the Mediterranean from the Atlantic during this period. However, it is more likely to mark a change in the overflow of Norwegian Sea water into the Rockall Trough.
\end{abstract}

\section{INTRODUCTION}

The Rockall Trough separates Rockall Plateau from the continental margin west of the British Isles (Fig. 1). DSDP Site 610 was drilled in the southern Rockall Trough near the crest of the Feni Ridge, a major sediment drift some $600 \mathrm{~km}$ long, situated along the western margin of the Trough (Jones et al., 1970; Ellett and Roberts, 1973). The base of the drift is recognized as a regional seismic reflector, R (Jones et al., 1970) or R4 (Roberts, 1975; Miller, 1982; Miller and Tucholke, 1983), which has been dated in the Labrador Sea and on Rockall Plateau as late Eocene to earliest Oligocene in age (Miller, 1982). As noted by Dingle et al. (1982), however, the published ages of the reflector identified as R4 and the regionally important older reflectors in the southern Rockall Trough are not well constrained. In the absence of local borehole data, dating was achieved by long-range correlation with Deep Sea Drilling Project sites in other parts of the northeast Atlantic (Roberts, 1975; Roberts et al., 1981).

This chapter presents a reassessment of the Tertiary seismic stratigraphy of the southern Rockall Trough in the light of the drilling results at Site 610. These results constrain the age of the Feni Drift, which, in turn, can be linked to changes in ocean circulation during the Tertiary. In particular, the influence and timing of the southward flow of Norwegian Sea water through the Rockall Trough can be assessed.

\section{MORPHOLOGY OF FENI RIDGE}

The Feni Ridge sediment drift is best developed between 52.5 and $55.5^{\circ} \mathrm{N}$ in the southwestern Rockall Trough (Fig. 2; Jones et al., 1970; Roberts and Kidd, 1979).

\footnotetext{
${ }^{1}$ Ruddiman, W. F., Kidd, R. B., Thomas, E., et al., Init. Repts. DSDP, 94: Washington (U.S. Govt. Printing Office).

2 Addresses: (Masson) Institute of Oceanographic Sciences, Wormley, Surrey, United Kingdom; (Kidd, present address) Dept. of Geology, University College of Swansea, Singleton Park, Swansea, SA2 8PP, Wales, United Kingdom.
}

North of $55.5^{\circ} \mathrm{N}$, the drift consists of a wedge of sediment built up against the steep eastern slope of Rockall Plateau (Fig. 3a). Here, no clear ridge axis is developed, and the seabed slopes gently down to the east, into the axis of Rockall Trough. South of $55.5^{\circ} \mathrm{N}$, a distinct, sinuous ridge crest is separated from the flank of Rockall Plateau by a broad depression (Figs. 2, 3b-f). This depression is up to $50 \mathrm{~km}$ wide and may be over $200 \mathrm{~m}$ deeper than the ridge crest. A channel or "moat" at the base of the steep eastern slope of Rockall Plateau is also seen on the three southern bathymetric profiles (Figs. 3d-f). Jones et al. (1970, their fig. 4) found a second ridge crest near $54^{\circ} \mathrm{N}, 15^{\circ} \mathrm{W}$, to the east of the main Feni Ridge crest. This small ridge is also seen on Figures $3 \mathrm{~b}$ and $3 \mathrm{c}$, but bathymetric maps show it to be a minor feature of only local importance (Fig. 2).

\section{SEISMIC STRATIGRAPHY}

\section{Previous Work}

The earliest detailed description of the seismic stratigraphy of the southern Rockall Trough was presented by Roberts (1975). He divided the sediment section into five sequences separated by four seismic reflectors of regional importance. These were labeled R4, X, Y, and Z and assigned ages of Oligocene-Eocene, mid-Paleocene (60 Ma), Campanian (76 Ma), and Cenomanian (approx. $100 \mathrm{Ma})$, respectively. Roberts et al. (1981) refined the earlier work and postulated a younger, mid-Paleocene age for reflector Y; this implied that reflector $\mathrm{X}$ must also be younger than previously suggested. An independent seismostratigraphic assessment of the southern Rockall Trough was proposed by Dingle et al. (1982), who recognized three regionally important reflectors named Challenger, Charcot, and Shackleton in order of increasing age. They correlated their Challenger reflector with R4 of Roberts (1975), agreeing that it was probably midPaleogene in age. No ages were proposed for Charcot and Shackleton. 


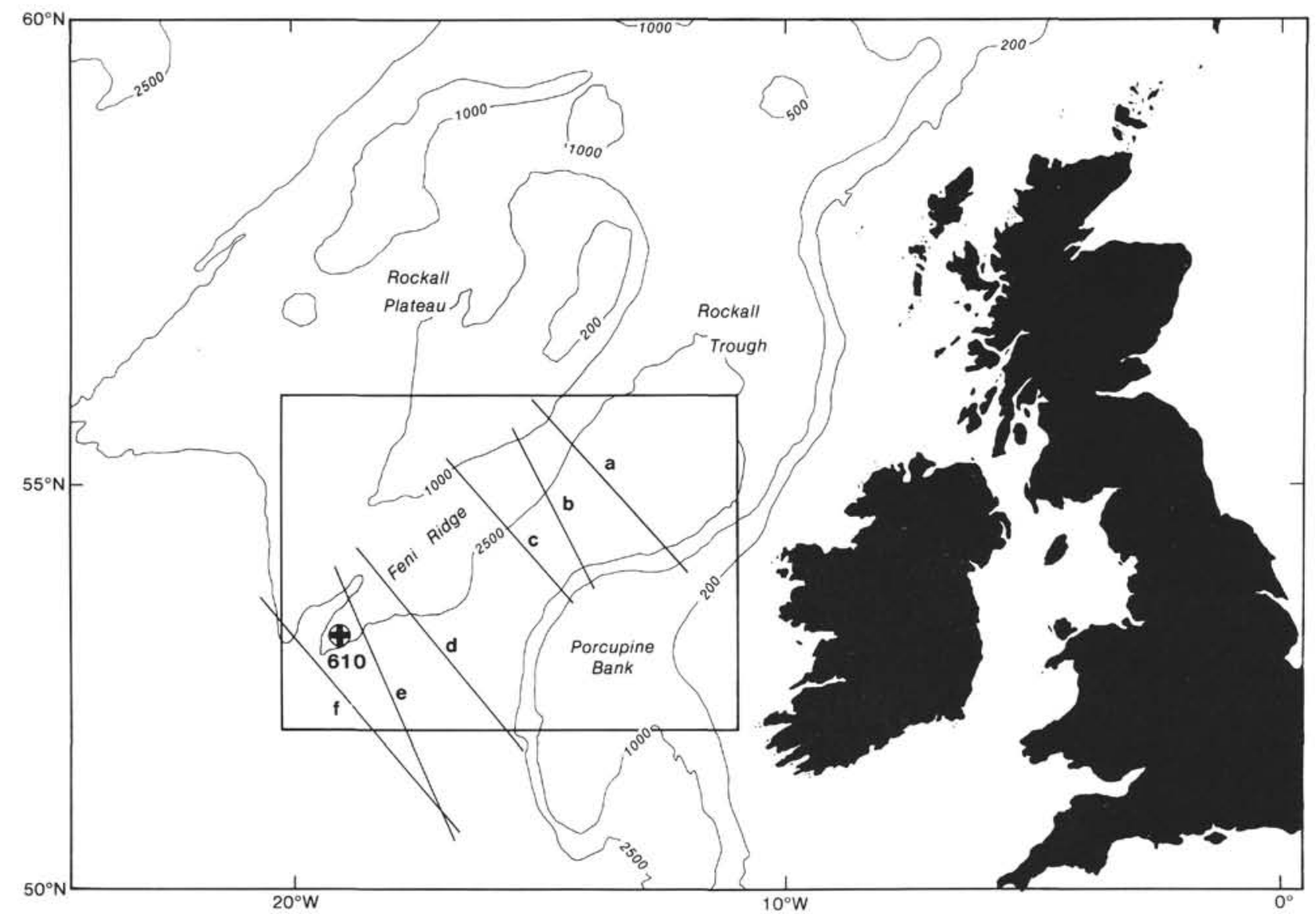

Figure 1. Map showing location of Site 610 in the southwestern Rockall Trough. Lines a-f are bathymetric profiles shown in Figure 3. Outlined rectangle is area of Figures 2 and 4 . Contours in meters.

\section{Seismic Reflection Profiles Used in the Present Study}

A large number of multichannel and single-channel seismic reflection profiles have been collected in the southern Rockall Trough (Fig. 4). The single-channel data, however, are of highly variable quality. Many of the lines were shot using a single, large-volume air gun, with the object of achieving maximum penetration into the thick sediment section. The resolution of such data is generally poor; many of the more subtle seismic events are masked by the elongated, low-frequency gun signal. The Discovery Cruise 84 profile, which runs just to the west of Site 610, is a good example of this, with a gun signal which is extended to around $0.5 \mathrm{~s}$ (all times are two-way traveltime) in length by low-frequency reverberation (Fig. 5). Only one seismic event, a confused package of reflections beginning at about $0.5 \mathrm{~s}$ below the seabed, can be recognized in the top $1.5 \mathrm{~s}$ of this profile (Fig. 5). The DSDP (Glomar Challenger) Leg 94 seismic data, for which a water gun was used as the sound source, are also disappointing, with very poor definition of reflectors below $0.25 \mathrm{~s}$ beneath the seabed and no reflectors below about $0.8 \mathrm{~s}$ (Fig. 6). The cause of this poor penetration is not known, but a low power output from the sound source (water gun) is suggested.

In contrast to the low-resolution single-channel data, the multichannel profiles provide a resolution of $0.1 \mathrm{~s}$ or better $(<100 \mathrm{~m})$ with no problems regarding the depth of seismic penetration. Although the multichannel profiles are limited in number (Fig. 4), their higher resolution makes them far more suitable for detailed seismostratigraphic studies than the single-channel profiles. For this reason, the following seismostratigraphic analysis is based mainly on multichannel profiles, in particular three profiles oriented NW-SE and crossing Feni Drift between 53 and $56^{\circ} \mathrm{N}$ (Fig. 2). The southernmost of these profiles crosses the crest of the drift some $90 \mathrm{~km}$ northeast of Site 610 . Correlation between site and the multichannel profile appears extremely good, despite this offset.

\section{Tertiary Seismic Stratigraphy of the Southern Rockall Trough}

On high-quality multichannel profiles, we recognized eight seismic reflectors, which can be correlated over all or most of the southern Rockall Trough. We have assigned a color code to each reflector; thus, the sequence is yellow, purple, green, brown, blue, pink, orange, and gray, in order of increasing age (Fig. 7, Table 1). Of these reflectors, the green ( $=$ R4 of Roberts, 1975, and Challenger of Dingle et al., 1982), brown ( = Charcot of Dingle et al., 1982), and blue (= X of Roberts, 1975) are of regional importance, dividing the section into four major sediment sequences (Table 1; Roberts, 1975; Roberts et al., 1981; Dingle et al., 1982).

The youngest, post-green sequence varies in thickness from $0.3 \mathrm{~s}$ beneath the axis of the southernmost Rockall 


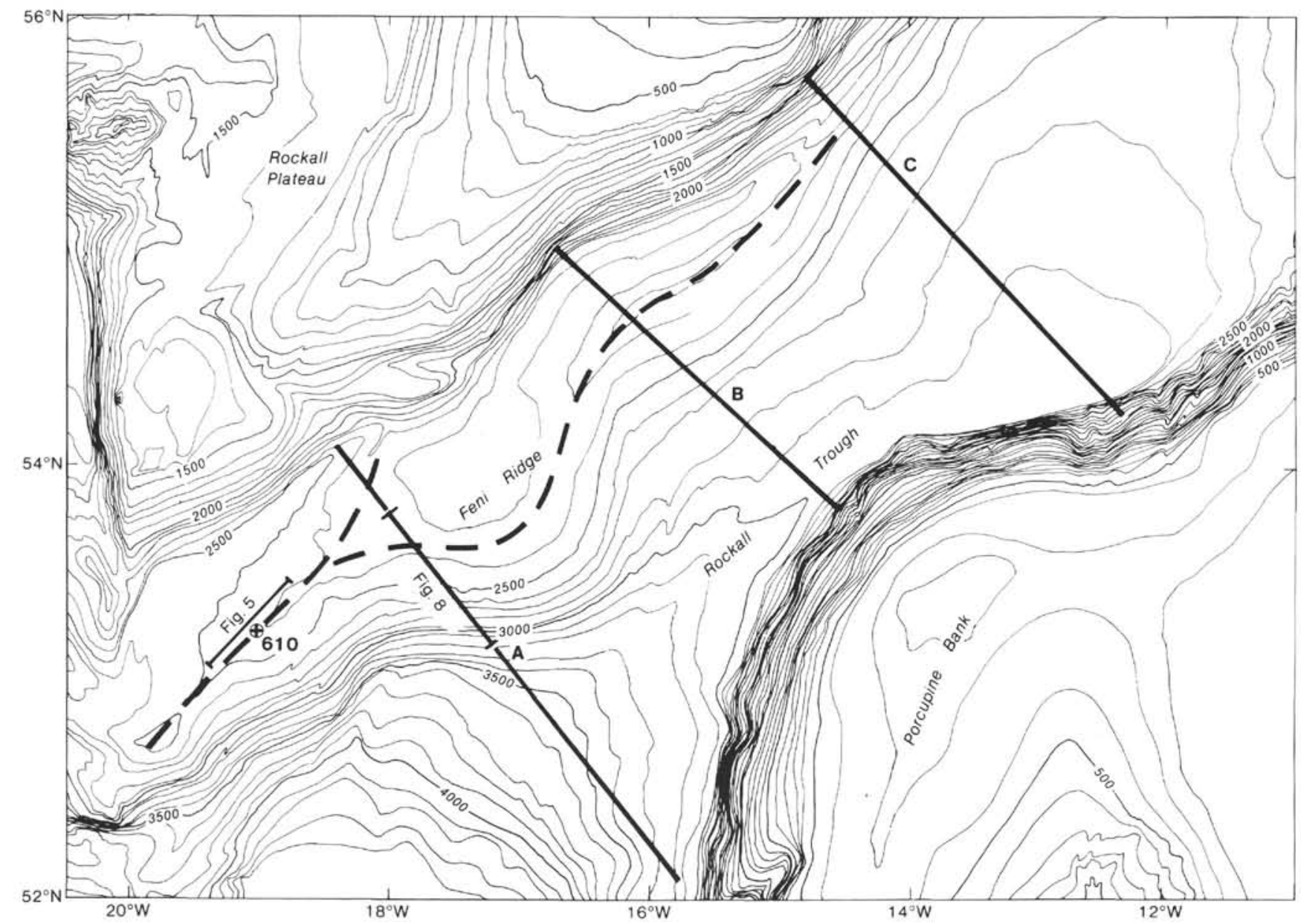

Figure 2. Detailed bathymetry of the southern Rockall Trough, showing the location of Site 610 on the crest of Feni Ridge. Heavy dashed line shows ridge crest. Profiles A-C are multichannel seismic reflection profiles illustrated in Figures 7 and 8 . Bathymetry in meters.

Trough to $0.8 \mathrm{~s}$ beneath Feni Drift (Fig. 7). In the east, this sequence is seismically transparent, whereas in the west, beneath Feni Drift, it is transparent in its upper half but moderately to strongly seismically layered in its lower part (Fig. 8), with the yellow reflector separating these subsequences. Both the yellow reflector and the purple, which occurs within the layered lower subsequence some 0.1 to $0.2 \mathrm{~s}$ above the green, can be traced only beneath Feni Drift; to the east they become indistinct and eventually disappear (Fig. 7).

The seismic profiles across Feni Drift show evidence of well-defined sediment waves only in the upper part of the sequence above the yellow reflector. They are best illustrated on the Glomar Challenger water-gun profiles around Site 610, where they are characteristic of the upper 0.1 to $0.15 \mathrm{~s}$ of the profile (Fig. 6). Amplitudes of individual waves appear to increase upsection, although it remains unclear whether this might be an acoustic artifact.

The upper, post-green reflector sequence is the only one that can be directly dated by the drilling results at Site 610 . Correlation of the drilling results with singlechannel seismic profiles in the immediate vicinity of the site is extremely difficult because of the limited resolution of these profiles (see earlier discussion and Site 610 report, this volume). We have therefore directly correlated Site 610 with multichannel profile A (Figs. 2, 7), even though this profile lies some $90 \mathrm{~km}$ north of the site, by assuming that the stratigraphy of Feni Drift does not change markedly when traced along the crest of the ridge for this distance. The good correlation between seismic reflectors and sonic velocity changes (Site 610 report, this volume) as measured in core samples appears to validate this assumption; all three reflectors correspond to increases in sonic velocity (Fig. 9). (Note that there are no major lithology changes in the sediments cored at Site 610 below the glacial cycles, which end at $135 \mathrm{~m}$ sub-bottom). These velocity increases occur in the uppermost upper Miocene (yellow reflector), mid-middle Miocene (purple reflector), and the uppermost lower Miocene (green reflector).

Below the green reflector, the green to brown reflector sequence ranges from moderately seismically layered in its upper part to transparent in its lower part (Fig. 8). The interval ranges from about $0.9 \mathrm{~s}$ thick beneath the southern part of Feni Drift' to about $0.4 \mathrm{~s}$ thick below the eastern Rockall Trough (Fig. 7).

The age of the brown reflector has not been directly established by drilling in Rockall Trough, but can be inferred from drilling results in other areas of the north- 


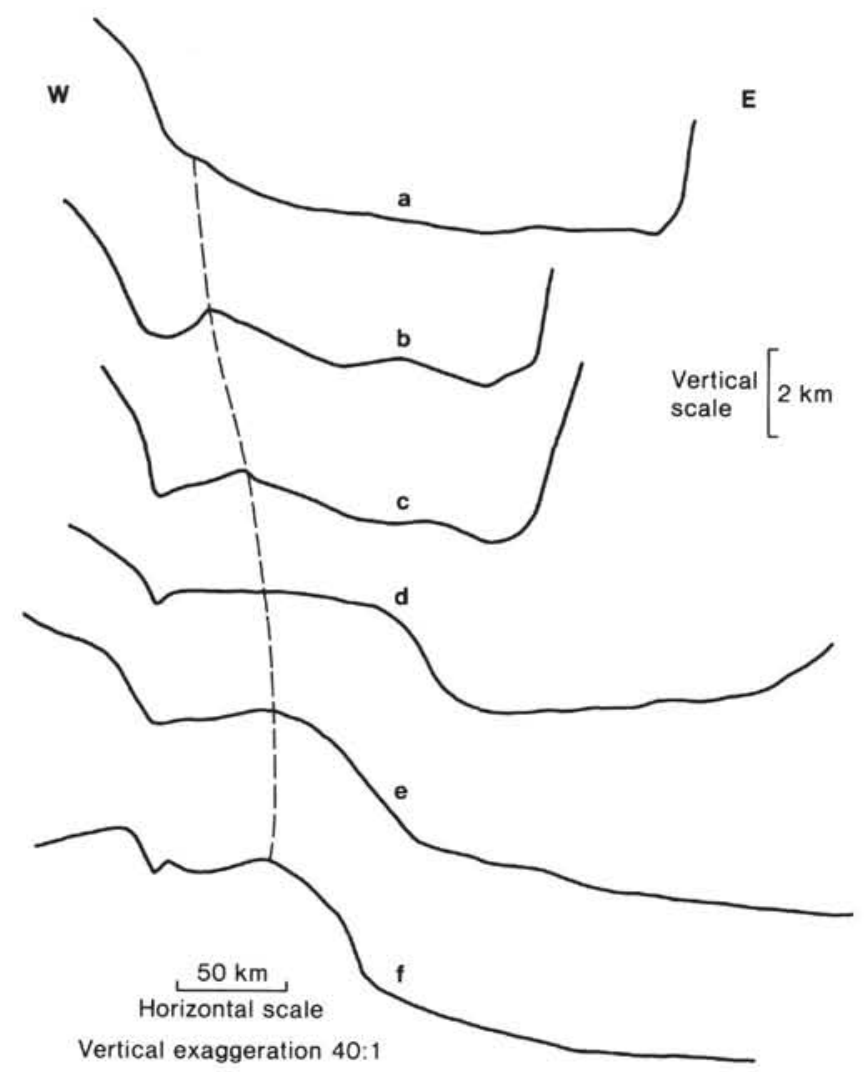

Figure 3. Series of NW-SE-oriented bathymetric profiles across Feni Ridge sediment drift between $56^{\circ} \mathrm{N}$ (profile a) and $52^{\circ} \mathrm{N}$ (profile $\mathrm{f}$ ). Locations of profiles on Figure 1. Dashed line marks ridge crest.

east Atlantic, from regional seismostratigraphic studies, and from sedimentation rate extrapolation. First, if the brown reflector is traced southward to DSDP Site 550 in the Porcupine Abyssal Plain at $48^{\circ} 30^{\prime} \mathrm{N}$, it can be seen to correlate with a hiatus of late Eocene to middle Oligocene age (Graciansky, Poag, et al., 1985). Second, it is clear that sediment drift construction began in the brown to green interval, with a considerably thicker sequence deposited beneath the Feni Drift than elsewhere (Fig. 7, profile A). Various authors have suggested that the change in North Atlantic abyssal circulation leading to sediment drift formation occurred in late Eocene to early Oligocene time (see summary by Miller, 1982, and Miller and Tucholke, 1983); the brown reflector may represent an event of this age. Third, an extrapoiation of the average sedimentation rate in the upper part of the sequence drilled at Site $610(\sim 48 \mathrm{~m} / \mathrm{m}$.y.) suggests an age of about $35 \mathrm{Ma}$ for the brown reflector. The time-vs.-depth curve for Site 610 may be offset at the levels of both the yellow and green reflectors (site report, this volume; Kidd and Hill, this volume), but it appears likely that overall sedimentation rates continued at around $50 \mathrm{~m} / \mathrm{m}$.y. The foregoing dates would also place the brown reflector in the lower Oligocene, although we accept that extrapolations of sedimentation rate are notoriously unreliable.

The sequence between the brown and blue reflectors ranges from 0.0 to $0.5 \mathrm{~s}$ in thickness, and is largely acoustically transparent. It is thickest beneath the axis of the Rockall Trough on seismic profiles B and C (Fig. 7), thinning both southward and toward the margins of the Trough.

The blue reflector can be dated by tracing it to DSDP Site 550 on the Porcupine Abyssal Plain at $48^{\circ} 30^{\prime} \mathrm{N}$, where it marks a hiatus of Santonian to early Maestrichtian age (Graciansky, Poag, et al., 1985). It is a particularly distinctive reflector beneath the Porcupine Abyssal Plain, separating a very transparent sequence below from a seismically layered sequence above (Masson et al., 1985), and is thus traced relatively easily northward into the Rockall Trough.

On seismic profile A, the blue to brown sequence is absent from the western half of the Trough beneath Feni Drift, with the blue reflector apparently truncated by the brown near the Trough axis (Fig. 7). A considerable hiatus of Late Cretaceous to late Eocene or early Oligocene age must occur in this part of Rockall Trough.

For the purposes of this chapter, the blue reflector will be taken as the base of the Tertiary. The Cretaceous sequence, within which the pink, orange, and gray reflectors occur, is outside the scope of this chapter and will not be discussed here.

\section{Correlation with Earlier Work}

The major finding of the Site 610 drilling results is that our green reflector, previously identified as R4 by Roberts (1975) and Roberts et al. (1981) and dated as late Eocene to early Oligocene, is in fact of late early Miocene age (Table 1). (Note that this change in reflector dating applies only to the Rockall Trough and not to Roberts's (1975) work on Rockall Plateau; that is, Roberts misidentified R4 in the Rockall Trough only.) The upper part of the Feni Drift sequence is therefore much younger than previously thought. The Challenger reflector of Dingle et al. (1982) is also the equivalent of the green reflector in the eastern Rockall Trough, but appears to be a combination of our yellow, purple, and green reflectors in the western Trough. The resolution of the single-channel seismic profiles of Dingle et al. made it impossible to separate these reflectors, and placed Challenger too high in the sediment section beneath Feni Drift. This interpretation led Dingle et al. to conclude that "postChallenger (sediment) thicknesses vary little" when, in fact, we see a 2- to 3-fold thickening beneath Feni Ridge on the multichannel profiles.

The lower Miocene reflector drilled at Site 610 appears to correlate with reflector R2 of Miller (1982), which occurs widely in the North Atlantic. Higher in the section, the yellow reflector may correlate with Miller's R1, a more localized event apparently recognized only in the northeast Atlantic (Miller, 1982; Miller and Tucholke, 1983).

Below the green reflector, where no drilling information is available, correlations necessarily become more speculative, but it appears from a direct comparison of seismic profiles that our brown reflector is the equivalent of the Charcot reflector of Dingle et al. (1982) and R4 of Miller (1982) and Miller and Tucholke (1983). Miller (personal communication, 1985) would disagree with this interpretation, placing R4 between our green and brown reflectors. He maintains that erosion and cur- 


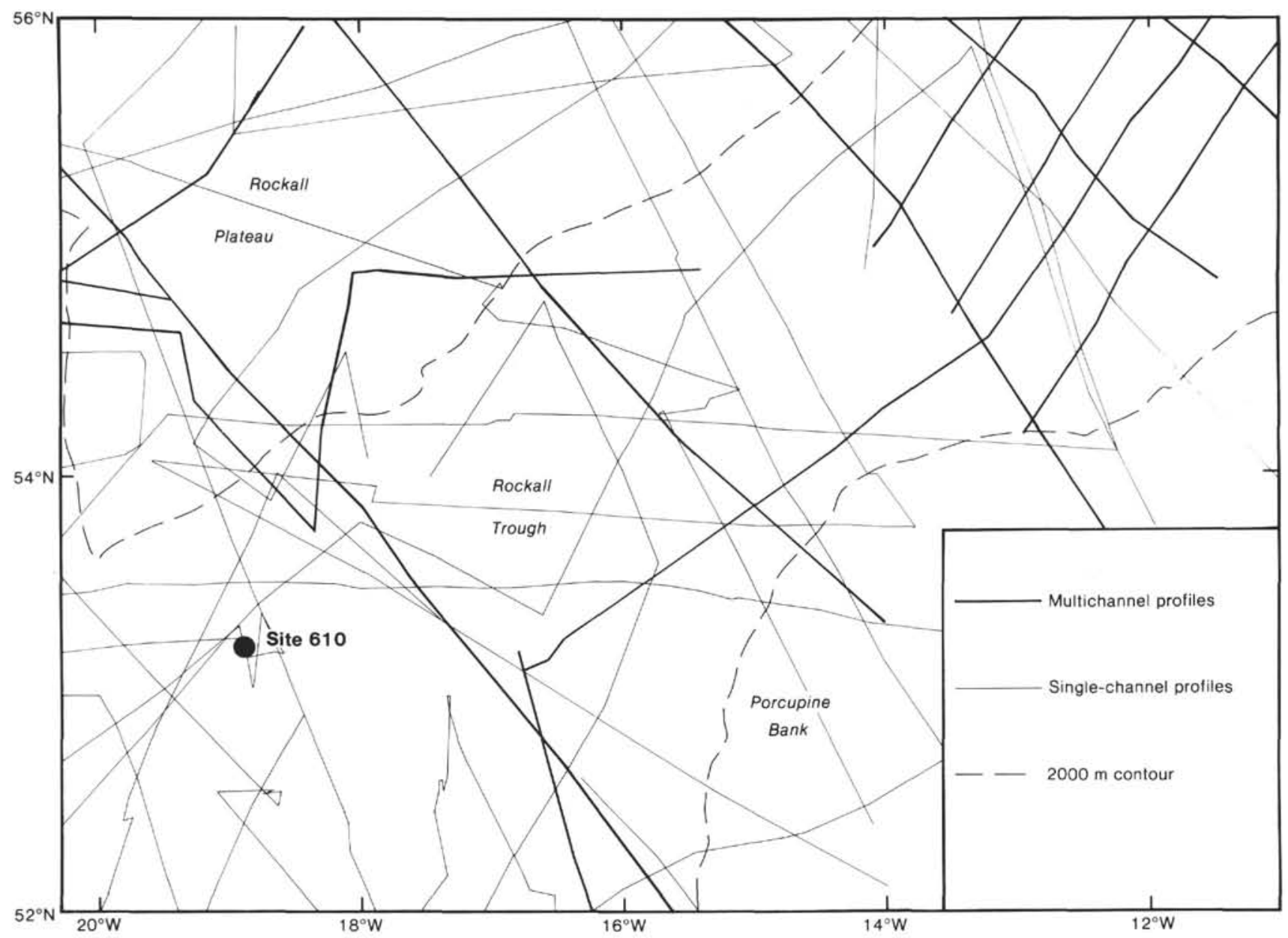

Figure 4. Locations of seismic reflection profiles in the study area. Figure is inner rectangle on Figure 1.

NE

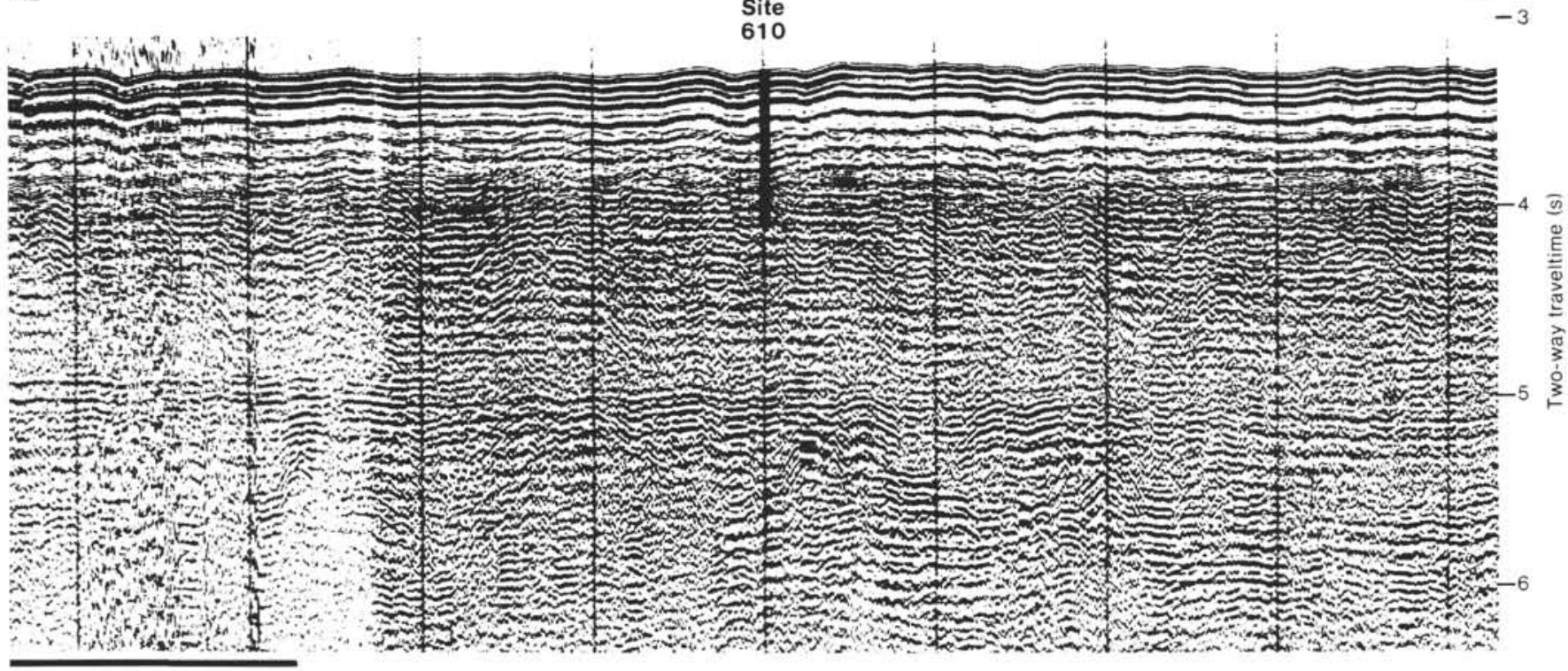

$10 \mathrm{~km}$

Figure 5. Single-channel seismic reflection profile through Site 610. Note the lack of resolution, resulting primarily from the elongated low-frequency air-gun signal. The poorly defined reflector at about $3.8 \mathrm{~s}$ appears to be a combination of the purple and green reflectors seen on higher-resolution multichannel seismic records. The reflector at $4.9 \mathrm{~s}$ is the brown reflector. Location of profile on Figure 2 (lower left). 

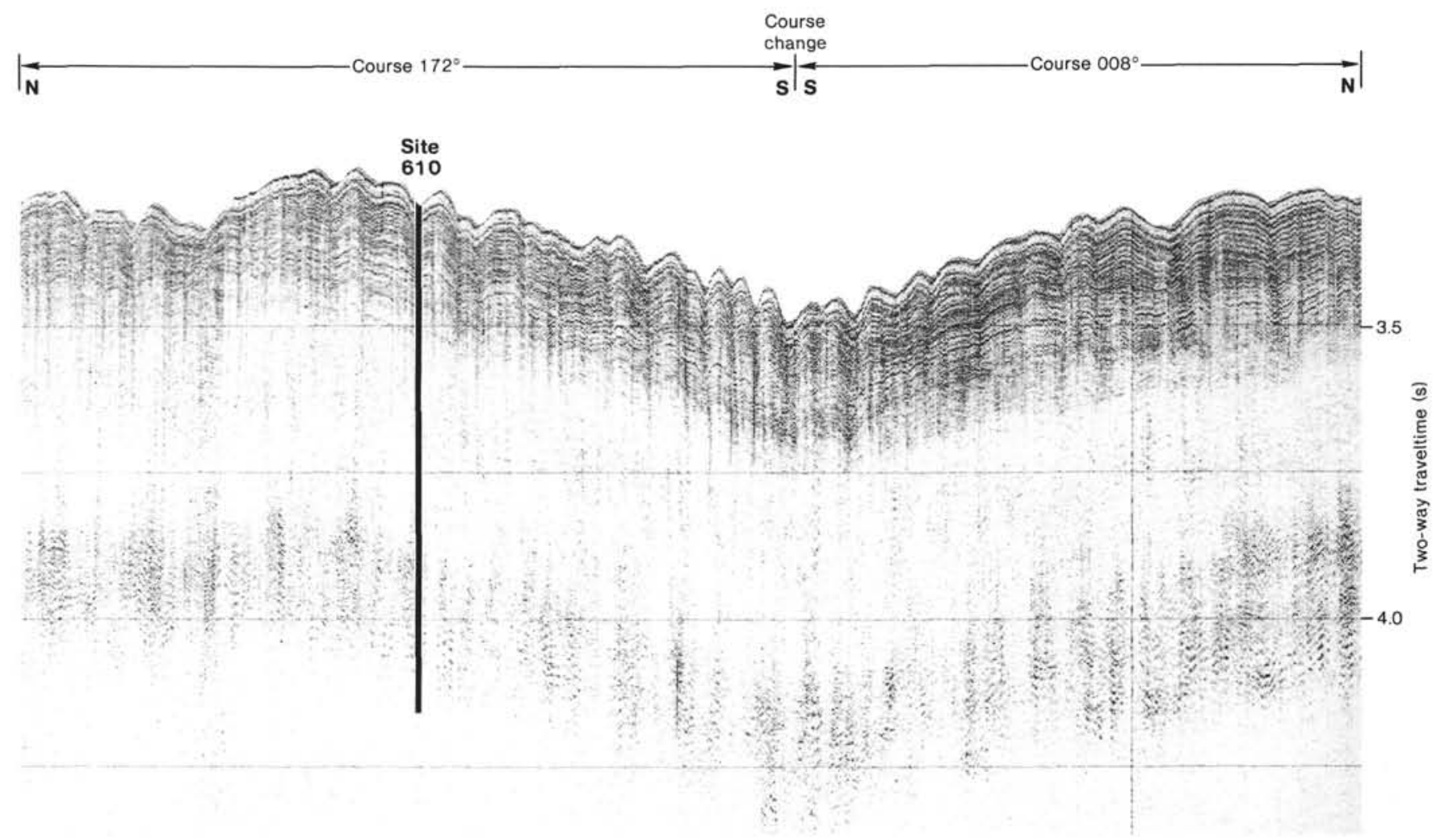

Figure 6. Glomar Challenger water-gun seismic reflection profile through Site 610, collected on Leg 94.

rent-controlled deposition began at the time of his R4, and attributes apparent lensing between his R4 and our brown to erosion at the level of his R4. He admits, however, that in the absence of direct evidence we cannot confirm either interpretation.

Our blue reflector is the equivalent of $\mathrm{X}$ of Roberts (1975) and Roberts et al. (1981). The dating of the blue reflector as Late Cretaceous is a substantial revision from the Eocene to Oligocene age proposed by Roberts et al. (1981). This revision has been made because new seismic data (D. G. Masson, unpublished data) across an area of the southernmost Rockall Trough, where reflector correlation has previously been equivocal, allows a much more reliable correlation with DSDP sites farther south on the continental margin. Furthermore, it is now recognized that the Paleocene age proposed for reflector $\mathrm{Y}$ (our pink) by Roberts et al. (1981) is not reliable, since the supposedly Paleocene igneous "events," which occur up to the stratigraphic level of reflector Y, are now believed to represent intrusions rather than lava flows, and as such have no direct age relationship to reflector $\mathrm{Y}$. This new interpretation is proposed because some of the high-amplitude reflectors arising from igneous "events" clearly cross-cut more laterally persistent sedimentary reflectors. Furthermore, drilling in present-day sediment basins where igneous activity is occurring (e.g., the Guaymas Basin in the Gulf of California) has shown that sill intrusion predominates over surface eruption of magma. The intrusion is driven by the hydrostatic pressure of the magma, and occurs because the magma is denser than the sediments (Einsele, 1982).
It is interesting that Roberts (1975) did not recognize that drift formation began in the brown to green interval (his X to R4), as is clearly demonstrated by our profiles, particularly toward the southern end of Feni Drift (Fig. 7, profile A). Dingle et al. (1982) did recognize driftrelated differential sedimentation in this interval (their Charcot to Challenger), but difficulty in dating reflectors led them to suggest that the differential sedimentation was evidence for pre-late Eocene bottom-current activity.

\section{DEVELOPMENT OF FENI DRIFT}

Seismic profiles across Feni Drift show that sediment drift construction is confined to the post-brown reflector interval. Because drilling did not penetrate the brown reflector, we cannot unequivocally date the initiation of drift formation, although a late Eocene to early Oligocene age is strongly suggested. A widespread seismic reflector of this age marks a change in sedimentation style throughout the North Atlantic, and is interpreted as marking the onset of strong abyssal circulation (see summary by Miller, 1982). It is often an unconformity at basin margins, and is especially well marked at drill sites around the Rockall Plateau. The strong abyssal circulation has persisted throughout the late Paleogene and Neogene, although periodic modifications of the circulation are indicated by changes in sedimentation patterns.

At Feni Drift, our green reflector is correlated with reflector R2 of Miller (1982), which he believed to be associated with a short interval of intensification of abyssal circulation. The unconformity correlated with $\mathrm{R} 2$ at 

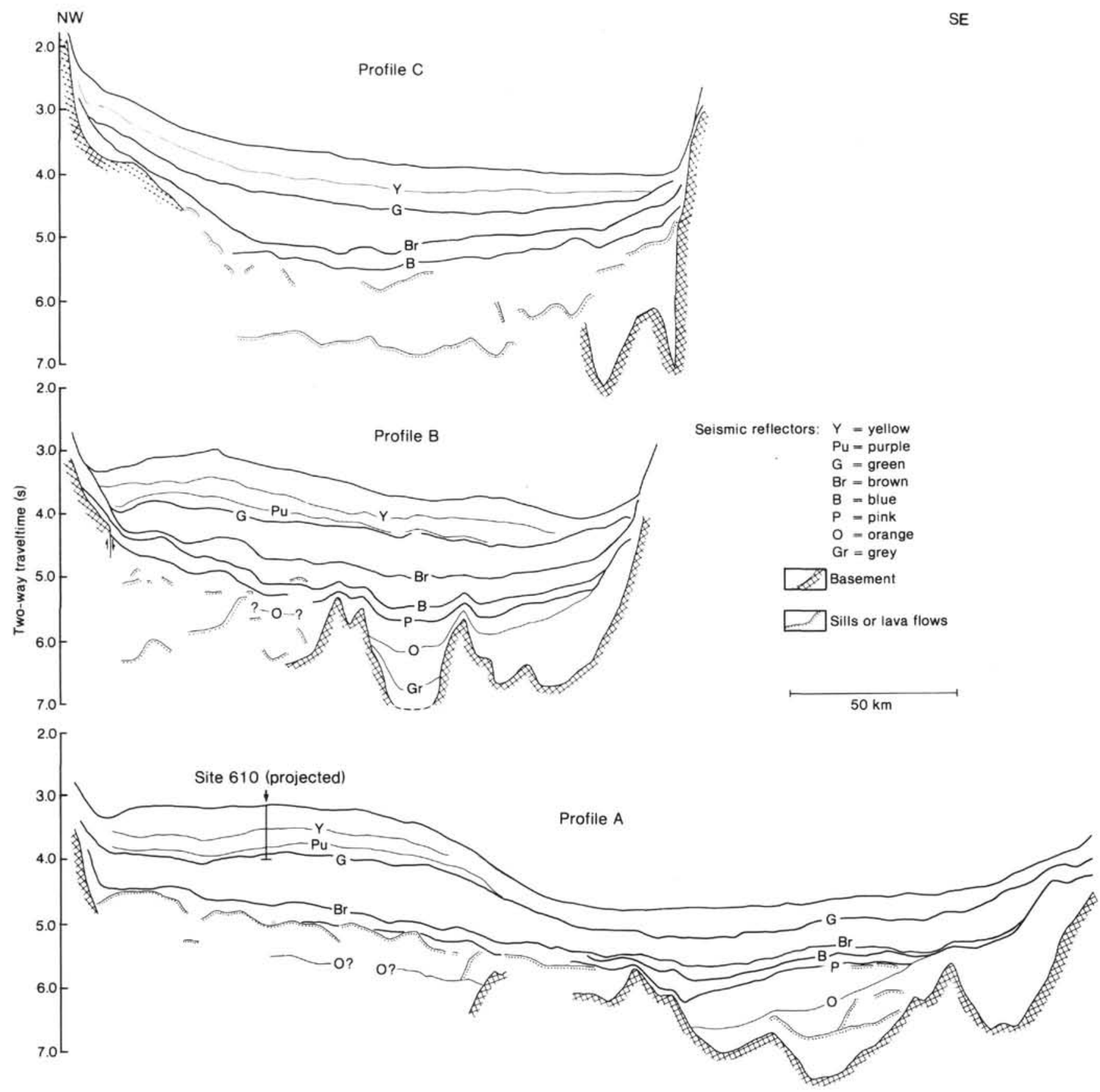

Figure 7. Series of interpreted, NW-SE-oriented, multichannel seismic reflection profiles across Feni Ridge sediment drift between $56^{\circ} \mathrm{N}$ (profile C) and $53^{\circ} \mathrm{N}$ (profile A). Vertical exaggeration is approximately $20: 1$. Note that sediment drift construction has occurred only in the postbrown reflector interval. Site 610 is about $90 \mathrm{~km}$ southwest of profile A. Locations of seismic profiles on Figure 2.

many drill sites in the northeast Atlantic (Miller and Tucholke, 1983) is not recognized at Site 610 however, although sedimentation rates may decrease to about $15 \mathrm{~m} /$ m.y. at the level of the green reflector (site report, this volume) and truncation of reflectors below the green reflector occurs elsewhere in the Trough (e.g., southeast end of Fig. 7) (see also Baldauf, this volume). The reflector itself results from a rapid increase in seismic velocity over the interval between 625 and $675 \mathrm{~m}$ sub-bottom (Fig. 9; site report, this volume), apparently related to an increase in hardness caused by compaction and silica diagenesis (Dolan, this volume). It is speculated that the increase in hardness and diagenesis is due to an oceanographic event (Baldauf, this volume), but the precise mechanism remains unclear.

The purple reflector at Site 610 also correlates with an increase in seismic velocity between 510 and $550 \mathrm{~m}$ sub-bottom (Fig. 9; site report, this volume). The spot coring in this part of Hole 610 does not, however, allow determination of the rate or cause of the velocity increase.

The yellow reflector at Site 610 is correlative with reflector R1 (Miller, 1982). This reflector is recognized in the Rockall Plateau area but not elsewhere in the North 


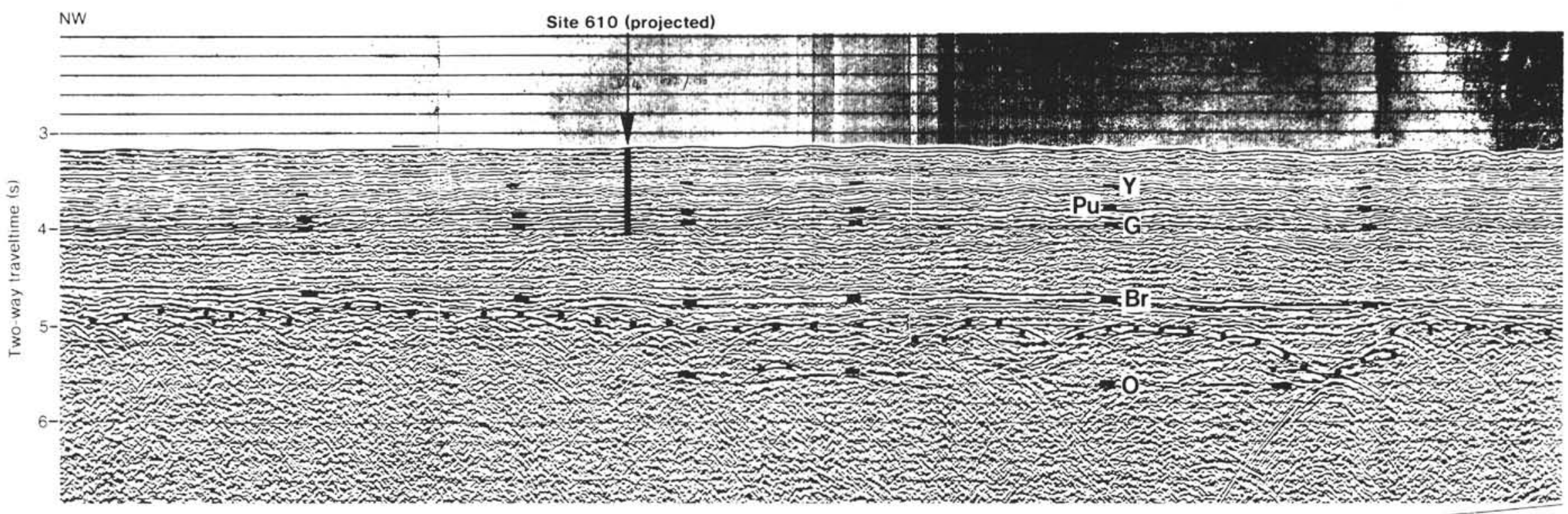

कs

Nons

in.

tin

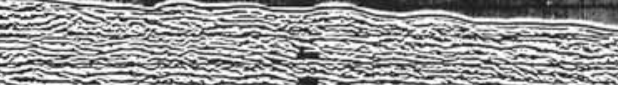

䙹

.

2.

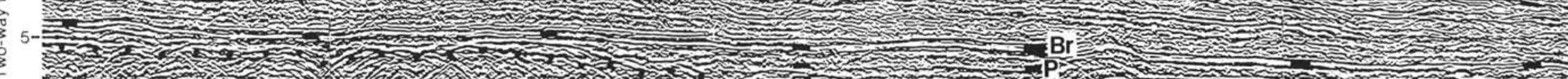

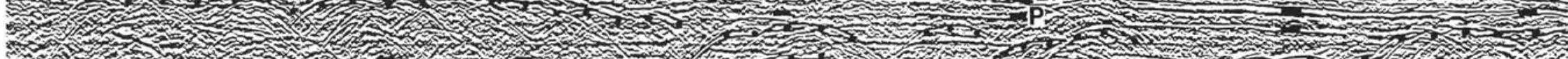
${ }_{6}$, Y.

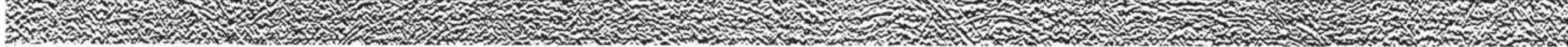

Figure 8. Multichannel seismic reflection profile across part of Feni Ridge sediment drift, showing seismic character of the drift and the relationship between the regionally important reflectors discussed in the text. Dashes mark reflectors $(\mathrm{Y}=$ yellow, $\mathrm{Pu}=$ purple, $\mathrm{G}=$ green, $\mathrm{Br}=$ brown, $\mathrm{P}=$ pink, $\mathrm{O}=$ orange). Dots mark igneous intrusions. Vertical exaggeration about 3:1. Location of profile on Figure 2 (segment of line A). Site 610 is projected from $90 \mathrm{~km}$ to the southwest. (Profile courtesy of Western Geophysical Company of America.) 
Table 1. Correlation of regionally important seismic reflectors identified by Roberts (1975), Roberts et al. (1981), Dingle et al. (1982), Miller (1982), Miller and Tucholke (1983), and the present authors.

\begin{tabular}{|c|c|c|c|c|}
\hline $\begin{array}{l}\text { Roberts (1975) and } \\
\text { Roberts et al. (1981) }\end{array}$ & $\begin{array}{l}\text { Dingle } \\
\text { et al. } \\
\text { (1982) }\end{array}$ & $\begin{array}{c}\text { Miller (1982) } \\
\text { and Miller and } \\
\text { Tucholke (1983) }\end{array}$ & $\begin{array}{l}\text { This } \\
\text { chapter }\end{array}$ & $\begin{array}{l}\text { Age } \\
\text { (this chapter) }\end{array}$ \\
\hline \multirow{3}{*}{ R4 } & & R1 & $\begin{array}{l}\text { Yellow (Y) } \\
\text { Purple (Pu) }\end{array}$ & \multirow{4}{*}{$\begin{array}{l}\text { latest late Miocene } \\
\text { mid-middle Miocene } \\
\text { latest early Miocene } \\
\text { late Eocene to early } \\
\text { Oligocene } \\
\text { Late Cretaceous }\end{array}$} \\
\hline & Challenger & R2 & Green (G) & \\
\hline & Charcot & R4? & Brown $(\mathrm{Br})$ & \\
\hline $\mathrm{x}$ & \multirow{4}{*}{ Shackleton } & & Blue (B) & \\
\hline $\mathrm{Y}$ & & & Pink $(\mathrm{P})$ & \multirow{3}{*}{$\begin{array}{l}\text { Late Cretaceous and } \\
\text { older }\end{array}$} \\
\hline & & & Orange $(\mathrm{O})$ & \\
\hline & & & Gray (Gr) & \\
\hline
\end{tabular}

Atlantic, according to Miller and Tucholke (1983). At Site 610 it correlates with an increase in seismic velocity between 300 and $345 \mathrm{~m}$ sub-bottom (Fig. 9; site report, this volume) and with a possible offset in the sedimentation rate curve between datums at 341 and $415 \mathrm{~m}$ subbottom (Fig. 9; site report, this volume). Miller (1982), noting that reflector R1 (our yellow reflector) was seen only in the Rockall Plateau area, suggested that it might have been caused by a local event related to compaction or diagenetic changes in the sediments. However, if there is an offset in the sedimentation rate curve at the level of the yellow reflector, then this does not support Miller's speculation. The offset represents an interval of reduced sedimentation rates, or nondeposition, or erosion, and indicates an oceanographic change or a change in the depositional environment. This is further supported by the presence of reworked foraminifers and nannofossils at the level of the offset (site report, this volume), indicating that at least some minor erosion may have taken place. The time interval of the reduced sedimentation rate spans nannofossil Zone NN10 and part of Zone NN11 (Takayama and Sato, this volume), and corresponds to the pre-Messinian period. During the Messinian the Mediterranean Sea became isolated from the Atlantic, possibly disturbing the oceanographic regime of the eastern Atlantic, where Mediterranean water is an important influence at the present time (Hsü et al., 1978; Reid, 1979; Gardner and Kidd, 1983; see also Keigwin et al., this volume). It is therefore possible that the yellow reflector might be related to this oceanographic disturbance and that this explains why it is localized to the eastern Atlantic. A Messinian disturbance is seen at Site 548 on Goban Spur to the south of Rockall Trough (Poag and Low, 1985), but is apparently not seen elsewhere on the Goban Spur or Bay of Biscay margins (Montadert, Roberts, et al., 1979; Graciansky, Poag, et al., 1985), where the effects of such a disturbance might be expected to be more severe than in Rockall Trough. This appears to suggest a northern source for the oceanographic disturbance. A second, more plausible, explanation must therefore be that the yellow "event" relates to a further brief perturbation in the overflow regime of Norwegian Sea water into the North Atlantic. Overflow events of this type appear to have controlled most sedimentation changes in the development of Feni Drift (Kidd and Hill, this volume).

\section{CONCLUSIONS}

The Tertiary sediments of the Feni Ridge can be divided into three seismic sequences. The upper two of these, representing upper Eocene to Recent sediments, show evidence of sediment drift accumulation in the form of differential deposition and sediment wave formation. Drilling at Site 610 penetrated to just below the boundary between the upper two sequences. This boundary, marked by a regionally important seismic reflector previously interpreted as the upper Eocene to lower Oligocene R4 reflector, proved to be of late early Miocene age. It correlates with the $\mathrm{R} 2$ event, which can be identified over wide areas of the North Atlantic. A further reflector, which subdivides the upper sequence, correlates with a period of reduced sedimentation rates or erosion during the latest late Miocene. This event, apparently restricted to the Rockall Plateau area, may have been related to the cutoff of Mediterranean water from the North Atlantic during this time, but it is more likely to have resulted from a change in Norwegian Sea overflow into the northern Rockall Trough.

\section{ACKNOWLEDGMENTS}

The work described here was part of a program of continental margin studies carried out for and funded by the U.K. Department of Energy. We thank Western Geophysical Company of America for permission to publish the seismic reflection profile shown in Figure 8. K. G. Miller and C. W. Poag reviewed the manuscript and made many helpful suggestions.

\section{REFERENCES}

Dingle, R. V., Megson, J. B., and Scrutton, R. A., 1982. Acoustic stratigraphy of the sedimentary succession west of Porcupine Bank, N.E. Atlantic Ocean: A preliminary account. Mar. Geol., 47:17-35.

Einsele, G., 1982. Mechanism of sill intrusion into soft sediment and expulsion of pore water. In Curray, J. R., Moore, D. G., et al., Init. Repts. DSDP, 64, Pt. 2: Washington (U.S. Govt. Printing Office), 1169-1176.

Ellett, D. J., and Roberts, D. G., 1973. The overflow of Norwegian Sea Deep Water across the Wyville-Thomson Ridge. Deep-Sea Res., 20:819-835.

Gardner, J. V., and Kidd, R. B., 1983. Sedimentary processes on the Iberian continental margin viewed by long-range sidescan sonar. Part 1: Gulf of Cadiz. Oceanol. Acta, 6:245-254.

Graciansky, P. C. de, Poag, C. W., et al., 1985. Init. Repts. DSDP, 80: Washington (U.S. Govt. Printing Office).

Hsü, K. J., Montadert, L., Bernoulli, D., Cita, M. B., Erickson, A., et al., 1978. History of the Mediterranean salinity crisis. In Hsü, K., Montadert, L., et al., Init. Repts. DSDP, 42, Pt. 1: Washington (U.S. Govt. Printing Office), 1053-1078. 
Jones, E. J. W., Ewing, M., Ewing, J. I., and Eittreim, S. L., 1970. Influences of Norwegian Sea Overflow Water on sedimentation in the northern North Atlantic and Labrador Sea. J. Geophys. Res., 75:1655-1680.

Masson, D. G., Montadert, L., and Scrutton, R. A., 1975. Regional geology of the Goban Spur continental margin. In Graciansky, P. C. de, Poag, C. W., et al., Init. Repts. DSDP, 80: Washington (U.S. Govt. Printing Office), 1115-1139.

Miller, K. G., 1982. Late Paleogene (Eocene to Oligocene) palaeoceanography of the northern North Atlantic [Ph.D. thesis]. Massachusetts Inst. of Technology, Woods Hole Oceanographic Inst.

Miller, K. G., and Tucholke, B. E., 1983. Development of Cenozoic abyssal circulation south of the Greenland-Scotland Ridge. In Bott, M. H. P., Saxov, S., Talwani, M., and Thiede, J. (Eds.), Structure and Development of the Greenland-Scotland Ridge. NATO Conference Series 4: Marine sciences (Vol. 8): New York and London (Plenum Press), 549-589.

Montadert, L., Roberts, D. G., et al., 1979. Init. Repts. DSDP, 48: Washington (U.S. Govt. Printing Office).
Poag, C. W., and Low, D., 1985. Environmental trends among Neogene benthic foraminifers at DSDP Site 548, Irish continental margin. In Graciansky, P. C. de, Poag, C. W., et al., Init. Repts. DSDP, 80: Washington (U.S. Govt. Printing Office), 489-504.

Reid, J. L., 1979. On the contribution of Mediterranean Sea outflow to the Norwegian-Greenland Sea. Deep-Sea Res., 26A:1194-1223.

Roberts, D. G., 1975. Marine geology of the Rockall Plateau and Trough. Phil. Trans. R. Soc. London, Ser. A, 278(1285):477-509.

Roberts, D. G., and Kidd, R. B., 1979. Abyssal sediment wave fields on Feni Ridge, Rockall Trough: Long-Range Sonar Studies. Mar. Geol., 33:175-191.

Roberts, D. G., Masson, D. G., and Miles, P. R., 1981. Age and structure of the southern Rockall Trough: New evidence. Earth Planet. Sci. Lett., 52:115-128.

Date of Initial Receipt: 21 November 1984

Date of Acceptance: 16 July 1985

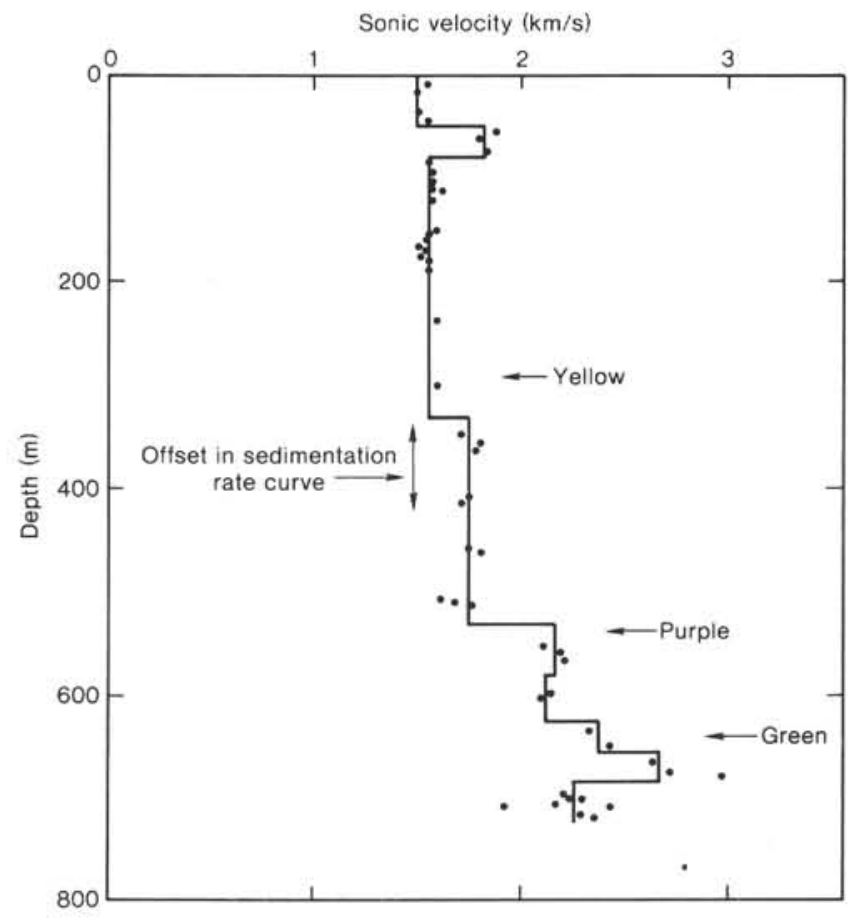

Figure 9. Correlation between sonic velocity measurements at Site 610 and seismic reflectors taken from seismic profile A (Figs. 6 and 7). Dots mark sonic velocity measurements. Continuous stepped line shows velocity function used to convert two-way traveltime to depth on the seismic reflection profile. The offset in the sedimentation rate curve is from Kidd and Hill (this volume). Note that all three seismic reflectors correlate with increases in sonic velocity. The slight mismatch between the yellow reflector and the sonic velocity increase at about $330 \mathrm{~m}$ is not considered significant, given that the well data have been projected some $90 \mathrm{~km}$ onto the seismic line. 